\title{
Non-Fullerene Small Molecular Acceptors Based on \\ Dithienocyclopentafluorene and Dithienocyclopentacarbazole Cores for \\ Polymer Solar Cells
}

Wangjun Guo, ${ }^{[\mathrm{a}], \dagger}$ Baofeng Zhao, ${ }^{[\mathrm{a}], \dagger}$ Jingming Xin, ${ }^{[\mathrm{b}]}$ Hongli Liu, ${ }^{[\mathrm{a}]}$ Yuhua Mi, ${ }^{[\mathrm{a}]}$ Jie Zhang, ${ }^{[\mathrm{a}]}$ Zhaoqi Guo, ${ }^{[\mathrm{a}]}$ Wei Wei, ${ }^{[\mathrm{c}]}$ Wei Ma, ${ }^{*}{ }^{[\mathrm{b}]}$ Chao Gao, ${ }^{*[\mathrm{a}]}$ Zhongwei An ${ }^{[\mathrm{a}]}$

${ }^{a}$ State Key Laboratory of Fluorine \& Nitrogen Chemicals, Xi'an Modern Chemistry Research Institute, Xi'an, Shaanxi, 710065, P. R. China.

${ }^{b}$ State Key Laboratory for Mechanical Behavior of Materials Xi'an Jiaotong University, Xi'an 710049, China.

${ }^{c}$ Nanjing University of Posts and Telecommunications, Nanjing 210003, P. R. China.

${ }^{\dagger}$ These authors contributed equally to this work.

Abstract: Recently, acceptor-donor-acceptor (A-D-A) type of small molecules based on indacenodithieno[3,2-b]thiophene (IDTT) or indacenodithiophene (IDT) as the electrondonating cores were very promising non-fullerene (NF) acceptors to overcome the energy levels and absorption drawbacks of the fullerene-based acceptors in polymer solar cells (PSCs). However, few attempts have been done to develop novel electron-donating cores to construct highly efficient A-D-A acceptors in PSCs. We design and prepare two novel non-fullerene small molecular acceptors (DTF-IC and DTC-IC) based on dithienocyclopentafluorene and dithienocyclopentacarbazole as the electron-donating cores sealed with 2-(3-oxo-indane-1-

${ }^{*}$ Corresponding author: Tel: (86)-29-88291190.

Email Address: msewma@mail.xjtu.edu.cn (W. Ma), chaogao1974@hotmail.com (C. Gao). 
ylidene)-malononitrile as the electron-withdrawing groups. The two molecules exhibit relatively high lowest unoccupied molecular orbital (LUMO) energy levels and strong absorption in the region from 550 to $740 \mathrm{~nm}$. Relative to the molecule DTF-IC possessing dithienocyclopentafluorene core, the dithienocyclopentacarbazole based acceptor DTC-IC shows slightly red-shifted absorption spectrum, enhanced extinction coefficients, better crystallinity and improved electron mobility. The polymer solar cells based on these two NF acceptors exhibit power conversion efficiencies of $7 \%$ when blended with the narrow bandgap polymer $\operatorname{poly}(\{4,8$-bis[(5-(2-ethylhexyl)-2-thienyl]benzo[1,2-b:4,5-b']dithiophene-2,6-diyl $\}\{3-$ fluoro-2-[(2-ethylhexyl)carbonyl]thieno[3,4-b]thiophenediyl\}) (PTB7-Th) in inverted solar cells.

Keywords: Polymer solar cells, Dithienocyclopentafluorene, Dithienocyclopentacarbazole, Nonfullerene small molecular acceptors.

\section{Introduction}

Bulk heterojunction (BHJ) polymer solar cells (PSCs), with a bicontinuous network by blending a p-type conjugated polymer as donor and an n-type fullerene derivative as acceptor in the active layer, have been intensively investigated for their advantages, such as light weight, flexibility, low cost, and suitability for large-scale fabrication. ${ }^{[1-3]}$ Up till now, state-of-the-art PSCs have already achieved power conversion efficiencies (PCEs) above $11 \%{ }^{[4-7]}$ However, the intrinsic drawbacks of the fullerene-based acceptors, such as weak absorption in the visible spectral region, restricted energy level variability, and inherent tendency of aggregation in the blend film, make it difficult to further increase the photovoltaic performance of this type of $\mathrm{P}$ S

C

S 
To overcome those drawbacks of fullerene-based acceptors, non-fullerene (NF) acceptors were developed in the past few years. ${ }^{[8]}$ At present, PSCs based on NF acceptors have been accomplished great progress, resulting in the realization of remarkable PCEs above $11 \%^{[9-10]}$ by blending acceptor-donor-acceptor (A-D-A) small molecular acceptors with suitable donor polymers, which can be compared with fullerene-based devices. A successful A-D-A type NF small molecular (ITIC) used indacenodithieno[3,2-b]thiophene (IDTT) as electron-donating core sealed with strong electron-withdrawing groups 2-(3-oxo-indane-1-ylidene)-malononitrile (INCN) developed by Zhan and co-workers is more attractive, ${ }^{[1]}$ for their strong absorptive properties in the range of $600-800 \mathrm{~nm}$ as well as adjustable energy levels to achieve complementary absorption with medium bandgap donor polymers to harvest the light in high energy region. Many A-D-A type NF acceptors based on IDTT and its derivatives as the electron-donating cores have been designed and achieved promising performances in the PSCs. For instances, through structural modification either in the side-chain of the IDTT core or in the end group, several novel ITIC-based NF small molecules with tuneable energy levels, carrier mobilities and absorption behaviours have been synthesized to promote the photovoltaic performances. ${ }^{[12-15]}$ However, few attempts have been done to develop novel electron-donating cores based A-D-A type NF small molecular acceptors with promising performance in PSCs. ${ }^{[16]}$

To investigate the influences of electron-donating cores on the performances of the A-D-A type NF acceptors and eventually obtain alternative novel acceptors, herein, we synthesize two small molecular electron acceptors (DTF-IC and DTC-IC, Scheme 1) based on dithienocyclopentafluorene (DTF) and dithienocyclopentacarbazole (DTC) as electron-donating units end-capped with INCN. DTF-IC and DTC-IC exhibit strong absorption in 550-740 nm, relative high lowest unoccupied molecular orbital (LUMO) energy levels, and good miscibility 
with polymer donors. PSCs fabricated by blending the promising narrow bandgap polymer based on benzodithiophene and thieno[3,4-b]thiophene units $\left(\mathbf{P T B 7 - \mathbf { T h } ^ { [ 1 7 ] } )}\right.$ as donor with DTFIC/DTC-IC as acceptors exhibited PCEs up to $7.0 \%$, indicating the promising performances of DTF and DTC based A-D-A types of small molecular NF acceptors.

\section{Experimental Section}

\subsection{Materials}

Unless noted, all the reactions were carried out under a nitrogen or argon atmosphere. Solvents were distilled under nitrogen over sodium (toluene), sodium/benzophenone (THF), and freshly distilled prior to use. Other materials were purchased from commercial resources and used without further purification. DTC-IC and DTF-IC were prepared according to the routes in

\section{Scheme 1.}
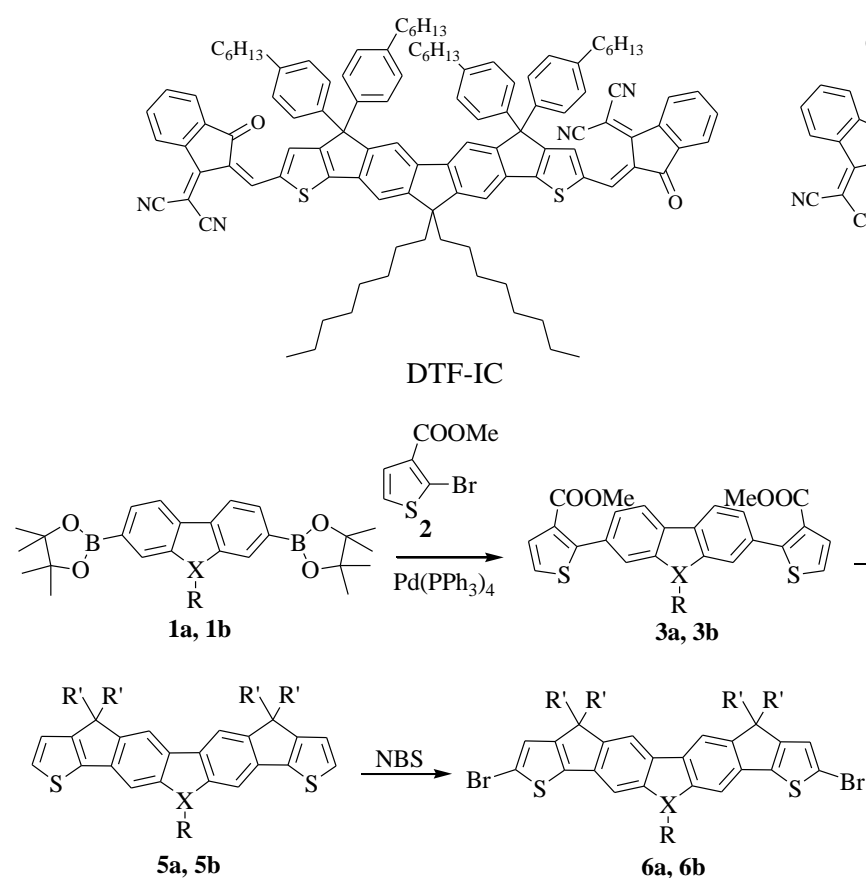

6a, $6 b$

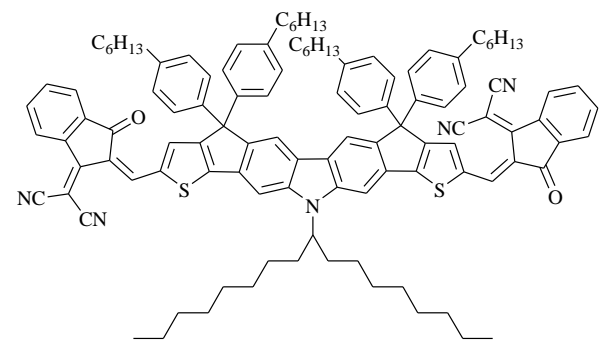

DTC-IC
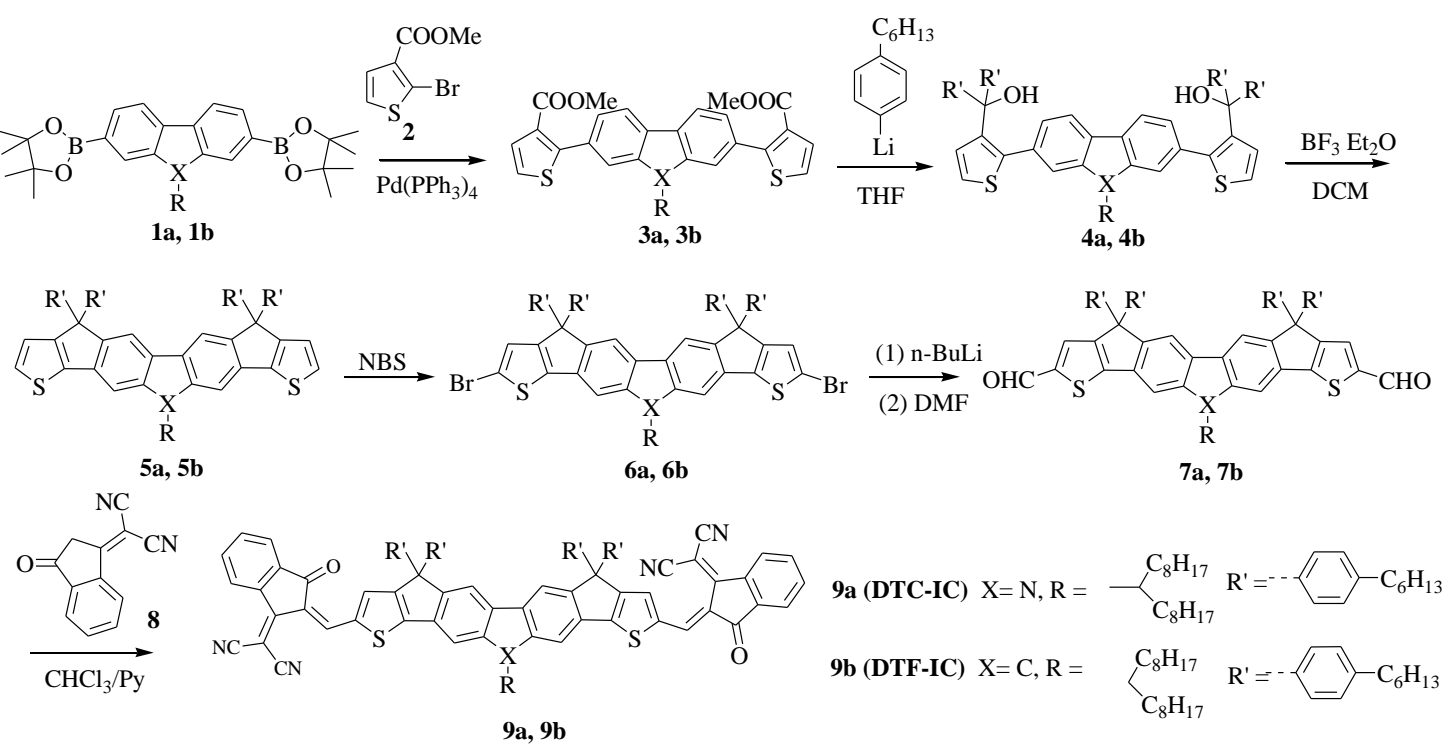
Scheme 1. Chemical structures and synthetic route of DTF-IC and DTC-IC.

\section{Synthesis of compound 3a}

2,7-Bis(4,4,5,5-tetramethyl-1,3,2-dioxaborolan-2-yl)-9-octyl-9H-carbazole (1a) (6.57 g, 10 mmol), methyl 2-bromothiophene-3-carboxylate (2) (5.4 g, 24 mmol), $\mathrm{K}_{2} \mathrm{CO}_{3}(8.2 \mathrm{~g}, 60 \mathrm{mmol})$, Aliquant $336(1.2 \mathrm{~g}, 3.0 \mathrm{mmol})$, and $\mathrm{Pd}\left(\mathrm{PPh}_{3}\right)_{4}(1.15 \mathrm{~g}, 1 \mathrm{mmol})$ were dissolved in deoxygenated toluene/ $\mathrm{H}_{2} \mathrm{O}(90 \mathrm{~mL}, 5: 1, \mathrm{v} / \mathrm{v})$. The reaction mixture was refluxed at $120{ }^{\circ} \mathrm{C}$ for $72 \mathrm{~h}$ and then extracted with diethyl ether $(100 \mathrm{~mL} \times 3)$ and water $(150 \mathrm{~mL})$. The collected organic layer was dried over $\mathrm{MgSO}_{4}$. After removal of the solvent under reduced pressure, the residue was purified by column chromatography on silica gel (hexane/dichloromethane, v/v, 20/1) to give a yellow liquid product 3a $(3.8 \mathrm{~g}, 56 \%) .{ }^{1} \mathrm{H}$ NMR $\left(\mathrm{CDCl}_{3}, 500 \mathrm{MHz}\right) \delta 8.15-8.05(2 \mathrm{H}, \mathrm{m}), 7.76(1 \mathrm{H}, \mathrm{s})$, $7.55(3 \mathrm{H}, \mathrm{d}, J=5.4 \mathrm{~Hz}), 7.36(2 \mathrm{H}, \mathrm{m}), 7.28(2 \mathrm{H}, \mathrm{d}, J=5.4 \mathrm{~Hz}), 4.58-4.52(1 \mathrm{H}, \mathrm{m}),, 3.72(6 \mathrm{H}$, s), $2.28(2 \mathrm{H}, \mathrm{m}), 1.93(2 \mathrm{H}, \mathrm{m}), 1.27-1.09(24 \mathrm{H}, \mathrm{m}), 0.81(6 \mathrm{H}, \mathrm{t}, J=7.1 \mathrm{~Hz}) .{ }^{13} \mathrm{C} \mathrm{NMR}\left(\mathrm{CDCl}_{3}\right.$, $126 \mathrm{MHz}) \delta 164.01,152.23,142.11,130.16,124.03,120.90,113.27,110.45,56.74,51.55,33.78$, $31.75,29.41,29.34,29.19,26.94,22.58,14.04$.

\section{Synthesis of compound 4a}

To a solution of 3a $(3.57 \mathrm{~g}, 7.8 \mathrm{mmol})$ in dry THF (100 mL) was added dropwise (4hexylphenyl)lithium which was freshly prepared by reacting 1-bromo-4-hexylbenzene $(11.3 \mathrm{~g}$, $46 \mathrm{mmol})$ with $2 \mathrm{M}$ n-butyllithium $(23.4 \mathrm{~mL}, 46.8 \mathrm{mmol})$ at $-78{ }^{\circ} \mathrm{C}$. The reaction mixture was warmed at room temperature and stirred for $12 \mathrm{~h}$. Then the mixture was quenched with water, followed by extraction with diethyl ether $(50 \mathrm{~mL} \times 3)$ and water $(100 \mathrm{~mL})$. The collected organic layer was dried over $\mathrm{MgSO}_{4}$. After removal of the solvent under reduced pressure, the residue was purified by column chromatography on silica gel (hexane/ dichloromethane, v/v, 10/1) to give a yellow liquid product $4 a(3.9 \mathrm{~g}, 60 \%) .{ }^{1} \mathrm{H} \mathrm{NMR}\left(\mathrm{CDCl}_{3}, 500 \mathrm{MHz}\right) \delta 7.86(1 \mathrm{H}, \mathrm{s}), 7.82$ $(1 \mathrm{H}, \mathrm{s}), 7.52(1 \mathrm{H}, \mathrm{s}), 7.38(1 \mathrm{H}, \mathrm{s}), 7.27(2 \mathrm{H}, \mathrm{d}, J=4.8 \mathrm{~Hz}), 7.25(2 \mathrm{H}, \mathrm{s}), 7.18(8 \mathrm{H}, \mathrm{d}, J=7.8 \mathrm{~Hz})$, 
$7.03-7.01(10 \mathrm{H}, \mathrm{m}), 4.64-4.49(1 \mathrm{H}, \mathrm{m}), 2.56-2.50(8 \mathrm{H}, \mathrm{m}), 2.36-2.24(2 \mathrm{H}, \mathrm{m}), 2.03-1.92$ $(2 \mathrm{H}, \mathrm{m}), 1.65-1.49(16 \mathrm{H}, \mathrm{m}), 1.35-1.12(41 \mathrm{H}, \mathrm{m}), 0.86(12 \mathrm{H}, \mathrm{t}, J=6.6 \mathrm{~Hz}), 0.79(6 \mathrm{H}, \mathrm{t}, J=$ $6.7 \mathrm{~Hz}) .{ }^{13} \mathrm{C} \mathrm{NMR}\left(\mathrm{CDCl}_{3}, 126 \mathrm{MHz}\right) \delta 156.38,144.97,141.06,128.18,127.91,127.15,123.35$, $62.21,56.80,35.57,33.79,31.76,31.73,31.33,29.50,29.33,29.20,29.17,27.00,22.60,14.09$, 14.04 .

\section{Synthesis of compound 5a}

To a solution of $4 \mathbf{a}(3.9 \mathrm{~g}, 1.2 \mathrm{mmol})$ in dichloromethane $(150 \mathrm{~mL})$ was added boron trifluoridediethyl etherate $(15 \mathrm{~mL})$. The reaction mixture was refluxed at $80{ }^{\circ} \mathrm{C}$ for $12 \mathrm{~h}$ and then was extracted with dichloromethane $(50 \mathrm{~mL} \times 4)$ and water $(100 \mathrm{~mL})$. The collected organic layer was dried over $\mathrm{MgSO}_{4}$. After removal of the solvent under reduced pressure, the residue was purified by column chromatography on silica gel (hexane) to give $\mathbf{5 a}$ as a yellow solid ( $3.2 \mathrm{~g}$, 83\%). ${ }^{1} \mathrm{H}$ NMR $\left(\mathrm{CDCl}_{3}, 500 \mathrm{MHz}\right) \delta 7.86(1 \mathrm{H}, \mathrm{s}), 7.83(1 \mathrm{H}, \mathrm{s}), 7.52(1 \mathrm{H}, \mathrm{s}), 7.38(1 \mathrm{H}, \mathrm{s}), 7.27$ $(1 \mathrm{H}, \mathrm{s}), 7.26(1 \mathrm{H}, \mathrm{s}), 7.18(8 \mathrm{H}, \mathrm{d}, J=8.3 \mathrm{~Hz}), 7.06-7.00(10 \mathrm{H}, \mathrm{m}), 4.63-4.49(1 \mathrm{H}, \mathrm{m}), 2.57-$ $2.48(8 \mathrm{H}, \mathrm{m}), 2.41-2.23(2 \mathrm{H}, \mathrm{m}), 2.00-1.94(2 \mathrm{H}, \mathrm{m}), 1.62-1.47(11 \mathrm{H}, \mathrm{m}), 1.39-1.09(46 \mathrm{H}$, m), $0.86(12 \mathrm{H}, \mathrm{t}, J=6.9 \mathrm{~Hz}), 0.79(6 \mathrm{H}, \mathrm{t}, J=6.9 \mathrm{~Hz}) .{ }^{13} \mathrm{C} \mathrm{NMR}\left(\mathrm{CDCl}_{3}, 126 \mathrm{MHz}\right) \delta 156.39$, 144.98, 143.08, 143.04, 141.08, 135.11, 134.66, 128.20, 127.93, 127.18, 123.36, 102.15, 99.54, $62.20,56.81,35.59,33.81,31.78,31.74,31.36,29.73,29.51,29.35,29.22,29.19,27.02,22.62$ 14.11, 14.07 .

\section{Synthesis of compound 6a}

N-bromosuccimide $(0.91 \mathrm{~g}, 5.7 \mathrm{mmol})$ was added in one portion to a solution of $\mathbf{5 a}(3.2 \mathrm{~g}$, $2.59 \mathrm{mmol})$ in THF $(60 \mathrm{~mL})$. The reaction was stirred under darkness for $12 \mathrm{~h}$ at room temperature. The mixture solution was extracted with diethyl ether $(60 \mathrm{~mL} \times 3)$ and water $(60$ $\mathrm{mL}$ ). The combined organic layer was dried over $\mathrm{MgSO}_{4}$. After removal of the solvent under 
reduced pressure, the residue was purified by column chromatography on silica gel (hexane) to give 6a as a yellow solid $(2.5 \mathrm{~g}, 83 \%) .{ }^{1} \mathrm{H} \mathrm{NMR}\left(\mathrm{CDCl}_{3}, 500 \mathrm{MHz}\right) \delta 7.83(1 \mathrm{H}, \mathrm{s}), 7.79(1 \mathrm{H}, \mathrm{s})$, $7.43(1 \mathrm{H}, \mathrm{s}), 7.29(1 \mathrm{H}, \mathrm{s}), 7.14(8 \mathrm{H}, \mathrm{d}, J=8.3 \mathrm{~Hz}), 7.03(8 \mathrm{H}, \mathrm{d}, J=8.3 \mathrm{~Hz}), 7.02(2 \mathrm{H}, \mathrm{s}), 4.69-$ $4.33(1 \mathrm{H}, \mathrm{m}), 2.64-2.45(8 \mathrm{H}, \mathrm{m}), 2.35-2.22(2 \mathrm{H}, \mathrm{m}), 1.96(2 \mathrm{H}, \mathrm{m}), 1.60-1.52(13 \mathrm{H}, \mathrm{m}), 1.29$ $-1.25(44 \mathrm{H}, \mathrm{m}), 0.86(12 \mathrm{H}, \mathrm{t}, J=6.9 \mathrm{~Hz}), 0.79(6 \mathrm{H}, \mathrm{t}, J=7.0 \mathrm{~Hz}) .{ }^{13} \mathrm{C} \mathrm{NMR}\left(\mathrm{CDCl}_{3}, 126 \mathrm{MHz}\right)$ $\delta 155.19,143.86,142.36,141.36,128.30,127.82,126.33,117.84,113.18,102.07,62.97,56.88$ $35.56,33.77,31.76,31.72,31.31,29.46,29.31,29.18,29.16,26.96,22.59,14.08,14.04$.

\section{Synthesis of compound 7a}

In a dry round-bottomed flask, compound $\mathbf{6 a}(970 \mathrm{mg}, 0.70 \mathrm{mmol})$ was dissolved in THF (50 $\mathrm{mL}$ ) and placed under a nitrogen atmosphere. The solution was cooled to $-78{ }^{\circ} \mathrm{C}$ and stirred while $2.0 \mathrm{M}$ n-butyllithium in hexane $(0.91 \mathrm{~mL}, 1.82 \mathrm{mmol})$ was added dropwise. The mixture was stirred for $1 \mathrm{~h}$ at $-78{ }^{\circ} \mathrm{C}$, and then anhydrous DMF $(1.32 \mathrm{~g}, 18.15 \mathrm{mmol})$ was added dropwise. The reactant was warmed to room temperature and stirred overnight. Thereafter, brine was added and extracted with dichloromethane. The resulting crude compound was purified by silica gel chromatography (hexane/dichloromethane, v/v, 20/1) to give 7a as a yellow solid (550 mg, 61\%). ${ }^{1} \mathrm{H} \mathrm{NMR}\left(\mathrm{CDCl}_{3}, 500 \mathrm{MHz}\right) \delta 9.84(2 \mathrm{H}, \mathrm{s}), 7.93(1 \mathrm{H}, \mathrm{s}), 7.89(1 \mathrm{H}, \mathrm{s}), 7.67(3 \mathrm{H}, \mathrm{s}), 7.54(1 \mathrm{H}, \mathrm{s})$, $7.17(8 \mathrm{H}, \mathrm{d}, J=8.3 \mathrm{~Hz}), 7.05(8 \mathrm{H}, \mathrm{d}, J=8.3 \mathrm{~Hz}), 4.80-4.49(1 \mathrm{H}, \mathrm{m}), 2.58-2.50(8 \mathrm{H}, \mathrm{m})$, 2.34-2.28 (2H, m), 2.06-1.99 (2H, m), $1.63-1.51(16 \mathrm{H}, \mathrm{m}), 1.39-1.09(41 \mathrm{H}, \mathrm{m}), 0.86(12 \mathrm{H}, \mathrm{t}$, $J=6.9 \mathrm{~Hz}), 0.77(6 \mathrm{H}, \mathrm{t}, J=6.9 \mathrm{~Hz}) .{ }^{13} \mathrm{C} \mathrm{NMR}\left(\mathrm{CDCl}_{3}, 126 \mathrm{MHz}\right) \delta 182.84,156.90,146.03$, $145.59,141.73,132.22,128.46,127.73,110.03,103.95,62.39,62.36,57.55,35.54,33.77,31.73$ $31.70,31.31,29.71,29.41,29.29,29.13,26.95,22.58,22.56,14.07,14.02$.

\section{Synthesis of compound 9a (DTC-IC)}


1,1-Dicyanamethylene-3-indanone (8) (30 $\mathrm{mg}, 0.154 \mathrm{mmol})$ was added into the mixture of compound $7 \mathbf{a}(50 \mathrm{mg}, 0.039 \mathrm{mmol})$ in chloroform $(10 \mathrm{~mL})$ with pyridine $(0.2 \mathrm{~mL})$, the reactant was deoxygenated with nitrogen for $30 \mathrm{~min}$ and then refluxed for $12 \mathrm{~h}$. After cooling to room temperature, the reaction was poured into water and then extracted with chloroform. The crude product was purified by silica gel column (chloroform) to give $\mathbf{9 a}$ as a purple solid (52 $\mathrm{mg}, 82 \%$ ). ${ }^{1} \mathrm{H}$ NMR $\left(\mathrm{CDCl}_{3}, 500 \mathrm{MHz}\right) \delta 8.93(1 \mathrm{H}, \mathrm{s}), 8.92(1 \mathrm{H}, \mathrm{s}), 8.70(1 \mathrm{H}, \mathrm{s}), 8.69(1 \mathrm{H}, \mathrm{s}), 7.99-7.86$ $(4 \mathrm{H}, \mathrm{m}), 7.84(1 \mathrm{H}, \mathrm{s}), 7.80-7.68(7 \mathrm{H}, \mathrm{m}), 7.17(8 \mathrm{H}, \mathrm{d}, J=8.3 \mathrm{~Hz}), 7.07(8 \mathrm{H}, \mathrm{d}, J=8.3 \mathrm{~Hz})$ $4.62-4.59(1 \mathrm{H}, \mathrm{m}), 2.61-2.51(8 \mathrm{H}, \mathrm{m}), 2.32-2.27(2 \mathrm{H}, \mathrm{m}), 2.11-2.05(2 \mathrm{H}, \mathrm{m}), 1.58-1.55$ $(14 \mathrm{H}, \mathrm{m}), 1.41-1.11(43 \mathrm{H}, \mathrm{m}), 0.86(12 \mathrm{H}, \mathrm{t}, J=6.9 \mathrm{~Hz}), 0.78(6 \mathrm{H}, \mathrm{t}, J=6.9 \mathrm{~Hz}) .{ }^{13} \mathrm{C}$ NMR $\left(\mathrm{CDCl}_{3}, 126 \mathrm{MHz}\right) \delta 188.75,147.25,141.92,141.54,140.68,134.35,128.57,127.76,125.42$ $123.66,114.78,102.45,101.18,62.35,57.53,35.55,31.74,31.70,31.29,29.38,29.32,29.12$, 27.11, 22.57, 14.06, 14.03.

\section{Synthesis of compound $3 \mathrm{~b}$}

2,7-Bis(4,4,5,5-tetramethyl-1,3,2-dioxaborolan-2-yl)-9,9-dioctyl-9H- fluorene (1b) (8.9 g, $13.9 \mathrm{mmol})$, methyl 2-bromothiophene-3- carboxylate (2) $(7.7 \mathrm{~g}, 34.7 \mathrm{mmol}), \mathrm{K}_{2} \mathrm{CO}_{3}(11.5 \mathrm{~g}$, $83.2 \mathrm{mmol})$, Aliquant $336(1.5 \mathrm{~g}, 3.8 \mathrm{mmol})$, and $\mathrm{Pd}\left(\mathrm{PPh}_{3}\right)_{4}(1.6 \mathrm{~g}, 1.39 \mathrm{mmol})$ were dissolved in deoxygenated toluene/ $\mathrm{H}_{2} \mathrm{O}(120 \mathrm{~mL}, 5: 1, \mathrm{v} / \mathrm{v})$. The reaction mixture was refluxed at $120{ }^{\circ} \mathrm{C}$ for $72 \mathrm{~h}$ and then extracted with diethyl ether $(100 \mathrm{~mL} \times 3)$ and water $(150 \mathrm{~mL})$. The collected organic layer was dried over $\mathrm{MgSO}_{4}$. After removal of the solvent under reduced pressure, the residue was purified by column chromatography on silica gel (hexane/dichloromethane, v/v, 20/1) to give a yellow liquid product $(3 \mathbf{b})(6.4 \mathrm{~g}, 55 \%) .{ }^{1} \mathrm{H} \mathrm{NMR}\left(\mathrm{CDCl}_{3}, 500 \mathrm{MHz}\right) \delta 7.74-$ $7.73(1 \mathrm{H}, \mathrm{m}), 7.73-7.72(1 \mathrm{H}, \mathrm{m}), 7.54(1 \mathrm{H}, \mathrm{s}), 7.53(1 \mathrm{H}, \mathrm{s}), 7.49(1 \mathrm{H}, \mathrm{d}, J=1.6 \mathrm{~Hz}), 7.48(1 \mathrm{H}$, d, $J=1.6 \mathrm{~Hz}), 7.46(2 \mathrm{H}, \mathrm{d}, J=1.1 \mathrm{~Hz}), 7.25(1 \mathrm{H}, \mathrm{s}), 7.24(1 \mathrm{H}, \mathrm{s}), 3.71(6 \mathrm{H}, \mathrm{s}), 2.08-1.90(4 \mathrm{H}$, 
m), $1.23-1.04(24 \mathrm{H}, \mathrm{m}), 0.80(6 \mathrm{H}, \mathrm{t}, J=5.9 \mathrm{~Hz}) .{ }^{13} \mathrm{C} \mathrm{NMR}\left(\mathrm{CDCl}_{3}, 201 \mathrm{MHz}\right) \delta 163.94$, $151.48,150.80,140.94,132.29,130.18,128.61,127.87,124.53,123.93,119.44,55.28,51.44$, $40.28,31.76,30.08,29.25,29.23,23.81,22.57,14.06$

\section{Synthesis of compound $4 \mathrm{~b}$}

To a solution of $\mathbf{3 b}(6.4 \mathrm{~g}, 9.5 \mathrm{mmol})$ in dry THF (100 mL) was added dropwise (4hexylphenyl)lithium which was freshly prepared by reacting 1-bromo-4-hexylbenzene (18 g, 73 mmol) with $2 \mathrm{M}$ n-butyllithium $(38 \mathrm{~mL}, 76 \mathrm{mmol})$ at $-78{ }^{\circ} \mathrm{C}$. The reaction mixture was warmed at room temperature and stirred for $12 \mathrm{~h}$. Then the mixture was quenched with water, followed by extraction with diethyl ether $(50 \mathrm{~mL} \times 3)$ and water $(100 \mathrm{~mL})$. The collected organic layer was dried over $\mathrm{MgSO}_{4}$. After removal of the solvent under reduced pressure, the residue was purified by column chromatography on silica gel (hexane/ dichloromethane, v/v, 10/1) to give a yellow liquid product (4b)(8.5 g, 57\%). ${ }^{1} \mathrm{H} \mathrm{NMR}\left(\mathrm{CDCl}_{3}, 500 \mathrm{MHz}\right) \delta 7.51(1 \mathrm{H}, \mathrm{s}), 7.50(1 \mathrm{H}, \mathrm{s})$, $7.23(1 \mathrm{H}, \mathrm{d}, J=1.5 \mathrm{~Hz}), 7.22(1 \mathrm{H}, \mathrm{d}, J=1.5 \mathrm{~Hz}), 7.16(8 \mathrm{H}, \mathrm{d}, J=8.3 \mathrm{~Hz}), 7.12-7.02(10 \mathrm{H}, \mathrm{m})$, $6.93(2 \mathrm{H}, \mathrm{d}, J=1.2 \mathrm{~Hz}), 6.44(1 \mathrm{H}, \mathrm{s}), 6.42(1 \mathrm{H}, \mathrm{s}), 2.64-2.58(8 \mathrm{H}, \mathrm{m}), 1.67-1.58(4 \mathrm{H}, \mathrm{m})$, $1.48-1.41(9 \mathrm{H}, \mathrm{m}), 1.39-1.27(26 \mathrm{H}, \mathrm{m}), 1.25-0.93(22 \mathrm{H}, \mathrm{m}), 0.93-0.87(12 \mathrm{H}, \mathrm{m}), 0.80(6 \mathrm{H}$, $\mathrm{t}, J=7.1 \mathrm{~Hz}) .{ }^{13} \mathrm{C} \mathrm{NMR}\left(\mathrm{CDCl}_{3}, 126 \mathrm{MHz}\right) \delta 151.04,145.56,144.16,141.90,140.30,139.24$, $133.54,131.53,129.09,127.94,127.59,124.00,122.39,119.79,80.78,54.98,39.56,35.64$ $31.84,31.78,31.70,31.55,29.96,29.35,29.28,29.11,23.69,22.66,22.66,14.14,14.09$.

\section{Synthesis of compound $5 \mathrm{~b}$}

To a solution of $\mathbf{4 b}(8.5 \mathrm{~g}, 6.8 \mathrm{mmol})$ in dichloromethane $(300 \mathrm{~mL})$ was added boron trifluoridediethyl etherate $(35 \mathrm{~mL})$. The reaction mixture was refluxed at $80{ }^{\circ} \mathrm{C}$ for $12 \mathrm{~h}$ and then was extracted with dichloromethane $(80 \mathrm{~mL} \times 4)$ and water $(100 \mathrm{~mL})$. The collected organic layer was dried over $\mathrm{MgSO}_{4}$. After removal of the solvent under reduced pressure, the residue 
was purified by column chromatography on silica gel (hexane) to give $\mathbf{5 b}$ as a yellow solid (4.4 g, 67\%). ${ }^{1} \mathrm{H}$ NMR $\left(\mathrm{CDCl}_{3}, 500 \mathrm{MHz}\right) \delta 7.51(2 \mathrm{H}, \mathrm{s}), 7.36(2 \mathrm{H}, \mathrm{s}), 7.25(2 \mathrm{H}, \mathrm{d}, J=4.9 \mathrm{~Hz}), 7.14$ $(8 \mathrm{H}, \mathrm{d}, J=8.2 \mathrm{~Hz}), 7.04(8 \mathrm{H}, \mathrm{d}, J=8.2 \mathrm{~Hz}), 6.99(2 \mathrm{H}, \mathrm{d}, J=4.9 \mathrm{~Hz}), 2.57-2.50(8 \mathrm{H}, \mathrm{m}), 2.00-$ $1.95(4 \mathrm{H}, \mathrm{m}), 1.61-1.49(10 \mathrm{H}, \mathrm{m}), 1.41-1.23(46 \mathrm{H}, \mathrm{m}), 0.86(12 \mathrm{H}, \mathrm{t}, J=6.8 \mathrm{~Hz}), 0.79(6 \mathrm{H}, \mathrm{t}, J$ $=7.0 \mathrm{~Hz}) .{ }^{13} \mathrm{C} \mathrm{NMR}\left(\mathrm{CDCl}_{3}, 126 \mathrm{MHz}\right) \delta 156.18,152.83,151.04,142.39,141.42,141.18$, $139.23,136.24,128.26,128.01,127.21,123.25,117.49,113.76,62.69,54.46,40.65,35.59$, $31.84,31.75,31.30,30.14,29.29,29.25,29.21,23.97,22.63,22.62,14.15,14.10$.

\section{Synthesis of compound $6 \mathrm{~b}$}

N-bromosuccimide $(1.4 \mathrm{~g}, 7.8 \mathrm{mmol})$ was added in one portion to a solution of $\mathbf{5 b}(4.4 \mathrm{~g}, 3.6$ $\mathrm{mmol})$ in THF $(100 \mathrm{~mL})$. The reaction was stirred under darkness for $12 \mathrm{~h}$ at room temperature. The mixture solution was extracted with diethyl ether $(60 \mathrm{~mL} \times 3)$ and water $(60 \mathrm{~mL})$. The combined organic layer was dried over $\mathrm{MgSO}_{4}$. After removal of the solvent under reduced pressure, the residue was purified by column chromatography on silica gel (hexane) to give $\mathbf{6 b}$ as a yellow solid (3.5 g, 71\%). ${ }^{1} \mathrm{H} \mathrm{NMR}\left(\mathrm{CDCl}_{3}, 500 \mathrm{MHz}\right) \delta 7.47(2 \mathrm{H}, \mathrm{s}), 7.28(2 \mathrm{H}, \mathrm{s}), 7.10(8 \mathrm{H}, \mathrm{d}$, $J=8.3 \mathrm{~Hz}), 7.04(8 \mathrm{H}, \mathrm{d}, J=8.3 \mathrm{~Hz}), 6.99(2 \mathrm{H}, \mathrm{s}), 2.59-2.51(8 \mathrm{H}, \mathrm{m}), 2.01-1.91(4 \mathrm{H}, \mathrm{m}), 1.57-$ $1.55(10 \mathrm{H}, \mathrm{m}), 1.38-1.04(46 \mathrm{H}, \mathrm{m}), 0.87(12 \mathrm{H}, \mathrm{t}, J=6.9 \mathrm{~Hz}), 0.80(6 \mathrm{H}, \mathrm{t}, J=7.1 \mathrm{~Hz},) .{ }^{13} \mathrm{C}$ NMR $\left(\mathrm{CDCl}_{3}, 126 \mathrm{MHz}\right) \delta 154.95,151.73,151.25,141.68,141.48,139.35,135.93,128.36$, $127.88,126.18,117.46,113.65,113.27,63.45,54.51,40.52,35.57,31.81,31.72,31.27,30.06$, $29.24,29.21,29.18,23.93,22.61,22.59,14.08$.

\section{Synthesis of compound $7 \mathrm{~b}$}

In a dry round-bottomed flask, compound $\mathbf{6 b}(0.93 \mathrm{~g}, 0.68 \mathrm{mmol})$ was dissolved in THF (50 $\mathrm{mL}$ ) and placed under a nitrogen atmosphere. The solution was cooled to $-78{ }^{\circ} \mathrm{C}$ and stirred while $2.0 \mathrm{M}$ n-butyllithium in hexane $(0.88 \mathrm{~mL}, 1.76 \mathrm{mmol})$ was added dropwise. The mixture 
was stirred for $1 \mathrm{~h}$ at $-78{ }^{\circ} \mathrm{C}$, and then anhydrous DMF $(1.32 \mathrm{~g}, 18.2 \mathrm{mmol})$ was added dropwise. The reactant was warmed to room temperature and stirred overnight. Thereafter, brine was added and extracted with dichloromethane. The resulting crude compound was purified by silica gel chromatography (hexane/dichloromethane, v/v, 20/1) to give a yellow solid (7b) (0.50g, 58\%). ${ }^{1} \mathrm{H} \mathrm{NMR}\left(\mathrm{CDCl}_{3}, 500 \mathrm{MHz}\right) \delta 9.76(2 \mathrm{H}, \mathrm{s}), 7.57(2 \mathrm{H}, \mathrm{s}), 7.50(2 \mathrm{H}, \mathrm{s}), 7.45(2 \mathrm{H}, \mathrm{s}), 7.05(8 \mathrm{H}, \mathrm{d}$, $J=8.3 \mathrm{~Hz}), 6.99(8 \mathrm{H}, \mathrm{d}, J=8.3 \mathrm{~Hz}), 2.51-2.45(8 \mathrm{H}, \mathrm{m}), 2.02-1.92(4 \mathrm{H}, \mathrm{m}), 1.56-1.46(10 \mathrm{H}$, m), $1.31-0.98(46 \mathrm{H}, \mathrm{m}), 0.79(12 \mathrm{H}, \mathrm{t}, J=6.9 \mathrm{~Hz}), 0.71(6 \mathrm{H}, \mathrm{t}, J=7.0 \mathrm{~Hz}) .{ }^{13} \mathrm{C}$ NMR $\left(\mathrm{CDCl}_{3}\right.$, $126 \mathrm{MHz}) \delta 182.81,156.69,154.25,152.05,151.28,145.65,141.85,141.18,141.14,135.32$, $132.16,128.53,127.79,118.04,115.59,62.90,54.79,40.43,35.54,31.77,31.69,31.24,29.96$, $29.70,29.18,29.13,23.98,22.57,14.05$.

\section{Synthesis of compound 9b (DTF-IC)}

1,1-Dicyanamethylene-3-indanone (8) $(0.091 \mathrm{~g}, 0.154 \mathrm{mmol})$ was added into the mixture of compound $7 \mathbf{b}(0.15 \mathrm{~g}, 0.039 \mathrm{mmol})$ in chloroform $(30 \mathrm{~mL})$ with pyridine $(0.62 \mathrm{~mL})$, the reactant was deoxygenated with nitrogen for 30 min and then refluxed for $12 \mathrm{~h}$. After cooling to room temperature, the reaction was poured into water and then extracted with chloroform. The crude product was purified by silica gel column (chloroform) to give a purple solid (9b) $(0.095 \mathrm{~g}, 50 \%)$. ${ }^{1} \mathrm{H} \mathrm{NMR}\left(\mathrm{CDCl}_{3}, 500 \mathrm{MHz}\right) \delta 8.90(2 \mathrm{H}, \mathrm{s}), 8.73-8.67(2 \mathrm{H}, \mathrm{m}), 7.93-7.90(2 \mathrm{H}, \mathrm{m}), 7.79-$ $7.72(4 \mathrm{H}, \mathrm{m}), 7.69(2 \mathrm{H}, \mathrm{s}), 7.68(2 \mathrm{H}, \mathrm{s}), 7.61(2 \mathrm{H}, \mathrm{s}), 7.13(8 \mathrm{H}, \mathrm{d}, J=8.4 \mathrm{~Hz}), 7.09(8 \mathrm{H}, \mathrm{d}, J=$ $8.4 \mathrm{~Hz}), 2.62-2.52(8 \mathrm{H}, \mathrm{m}), 2.05-2.03(4 \mathrm{H}, \mathrm{m}), 1.58(10 \mathrm{H}, \mathrm{m}), 1.38-1.10(46 \mathrm{H}, \mathrm{m}), 0.87$ $(12 \mathrm{H}, \mathrm{t}, J=6.9 \mathrm{~Hz}), 0.80(6 \mathrm{H}, \mathrm{t}, J=7.0 \mathrm{~Hz}) .{ }^{13} \mathrm{C} \mathrm{NMR}\left(\mathrm{CDCl}_{3}, 126 \mathrm{MHz}\right) \delta 188.40,160.58$, $160.30,157.79,155.52,152.88,142.44,142.06,140.80,140.70,139.99,139.64,138.62,136.95$, $135.79,135.05,134.39,128.65,127.83,125.30,123.72,121.74,118.47,116.52,114.75,68.78$ 
$62.92,54.66,40.32,35.56,31.78,31.70,31.26,30.03,29.25,29.20,29.13,24.17,22.61,22.58$, 14.07 .

\subsection{Measurements}

All compounds were characterized by nuclear magnetic resonance spectra (NMR) recorded on a Bruker AV 500 or 800 spectrometer in $\mathrm{CDCl}_{3}$ at room temperature using tetramethylsilane (TMS) as an internal reference at room temperature. The chemical shifts were accounted in ppm related to the singlet of $\mathrm{CDCl}_{3}$ at $7.26 \mathrm{ppm}$ and $77 \mathrm{ppm}$ for ${ }^{1} \mathrm{H}$ and ${ }^{13} \mathrm{C}$ NMR, respectively. The absorption spectra were measured using a PerkinElmer Lambda 750 UV/Vis/NIR Spectrometer. Thermogravimetric analysis (TGA) was performed on a Universal V2.6D TA instrument. Photoluminescence spectra of the pure and blend films were measured on a fluorospectro photometer (Edinburgh Instruments, FLSPP20). The electrochemical cyclic voltammetry was conducted on a CHI 660D Electrochemical Workstation equipped with glassy carbon, Pt wire, and $\mathrm{Ag} / \mathrm{Ag}^{+}$as working electrode, counter electrode, and reference electrode respectively in a 0.1 $\mathrm{mol} / \mathrm{L}$ tetrabutylammonium hexafluorophosphate $\left(\mathrm{Bu}_{4} \mathrm{NPF}_{6}\right)$ acetonitrile solution. Atomic force microscopy (AFM) measurement of the surface morphology of samples was conducted in air under ambient conditions using the DI MultiMode Nanoscope IIIa (Veeco). The thickness of the active layer of the device was measured using Bruker Dektak-XT surface profiler.

\subsection{Fabrication and characterization of OSCs}

The inverted device structure of the OSCs was ITO/ZnO $(40 \mathrm{~nm}) /$ poly[ $(9,9-$ dioctyl-2,7fluorene)-alt-(9,9-bis(3-N,N-dimethylamino)propyl)-2,7-fluorene $\quad$ (PFN, $10 \quad \mathrm{~nm}$ )/PTB7Th:acceptors $(80-90 \mathrm{~nm}) / \mathrm{MoO}_{3}(10 \mathrm{~nm}) / \mathrm{Al}(100 \mathrm{~nm})$. The ITO glass was ultrasonically cleaned with detergent, distilled water, acetone, isopropyl alcohol, and then treated with ultraviolet-ozone (Ming Heng, PDC-MG) for $20 \mathrm{~min}$. Zinc acetate dihydrate dissolved in 2-methoxyethanol and a 
small amount of ethanolamine was spin-cast on ITO substrates and baked at $200{ }^{\circ} \mathrm{C}$ for 30 minutes in the air to form a $\mathrm{ZnO}$ layer with a thickness of $40 \mathrm{~nm}$. The substrates were transferred into a nitrogen filled glove box, then the PFN $\left(0.5 \mathrm{mg} \mathrm{ml}^{-1}\right)$ methanol solution was spin-coated the on the top of $\mathrm{ZnO}$ layer at $2000 \mathrm{rpm}$ for $20 \mathrm{sec}$. The photoactive layer $(80-90 \mathrm{~nm})$ was then prepared by spin-coating a blend solution of the acceptors and PTB7-Th in orthodichlorobenzene (oDCB) on the top of ITO/ZnO/PFN substrate. The weight ratios of PTB7-Th and acceptors were varied from 1:1 to $1: 1.5$ to optimize the device performances. The total concentration was fixed at $25 \mathrm{mg} \mathrm{ml}^{-1}$ for all blend solutions. Finally, the films were transferred into a vacuum evaporator and $\mathrm{MoO}_{3}(10 \mathrm{~nm})$ and $\mathrm{Al}(120 \mathrm{~nm})$ were evaporated through a shadow mask $\left(0.16 \mathrm{~cm}^{2}\right)$ under vacuum onto the active layer. The current density -voltage $(J-V)$ curves of devices were measured by using a Keithley 2400 source meter. The PCE was tested under Air Mass 1.5 Global (AM 1.5G) illumination of $100 \mathrm{~mW} \mathrm{~cm}^{-2}$ (Newport Solar Simulator 94021A). A monocrystal silicon cell (VLSI Standards Inc.) calibrated by the National Renewable Energy Laboratory (NREL) was used as a reference. The external quantum efficiency (EQE) spectra of the devices were measured on a hypermonolight system (QTEST $1000 \mathrm{AD}$, Crowntech Inc.).

\subsection{Mobility measurement}

Space-charge limited current (SCLC) method was used to measure the hole and electron mobilities with a hole-only devices structure of ITO/PEDOT:PSS/active layer/ $/ \mathrm{MoO}_{3} / \mathrm{Al}$ and and an electron-only device architecture of ITO/ZnO/PFN/active layer/PFN/Al, by taking the dark current density in the range of $0-8 \mathrm{~V}$ and fitting the results to a space charge limited form. SCLC is described by the equation: $\mathrm{J}=9 \varepsilon_{0} \varepsilon_{r} \mu_{0} V^{2} / 8 L^{3}$, where $\mathrm{J}$ is the current density, $\varepsilon_{0}$ is the permittivity of free space, $\varepsilon_{r}$ is the relative dielectric constant of the transport medium, $\mu_{0}$ is the 
hole or electron mobility, and $\mathrm{V}$ is the effective voltage. The effective voltage can be obtained by subtracting the built-in voltage $\left(\mathrm{V}_{\mathrm{bi}}\right)$ and the voltage drop $\left(\mathrm{V}_{\mathrm{s}}\right)$ from the substrate's series resistance from the applied voltage $\left(\mathrm{V}_{\mathrm{appl}}\right), \mathrm{V}=\mathrm{V}_{\mathrm{appl}}-\mathrm{V}_{\mathrm{bi}}-\mathrm{V}_{\mathrm{s}}$. The hole-mobility can be calculated from the slope of the $\mathrm{J}^{1 / 2} \sim \mathrm{V}$ curves.

\subsection{Grazing Incidence Wide-Angle X-ray Scattering (GIWAXS) Characterization}

GIWAXS measurements were performed at beamline 7.3.3 $3^{[18]}$ at the Advanced Light Source. Samples were prepared on Si substrates using identical blend solutions as those used in devices. The $10 \mathrm{keV}$ X-ray beam was incident at a grazing angle of $0.12^{\circ}-0.16^{\circ}$, selected to maximize the scattering intensity from the samples. The scattered x-rays were detected using a Dectris Pilatus $2 \mathrm{M}$ photon counting detector.

\section{Results and discussion}

\subsection{Materials design and synthesis}
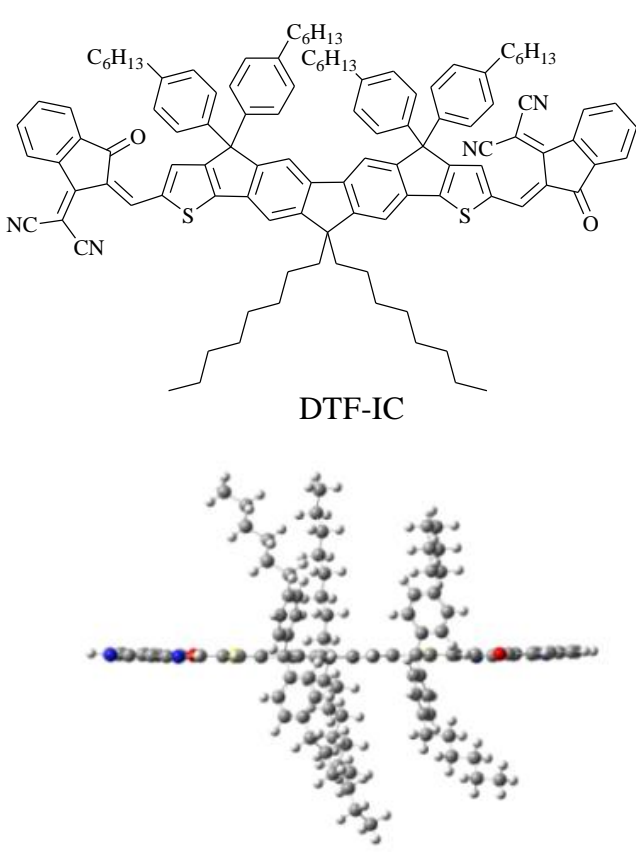

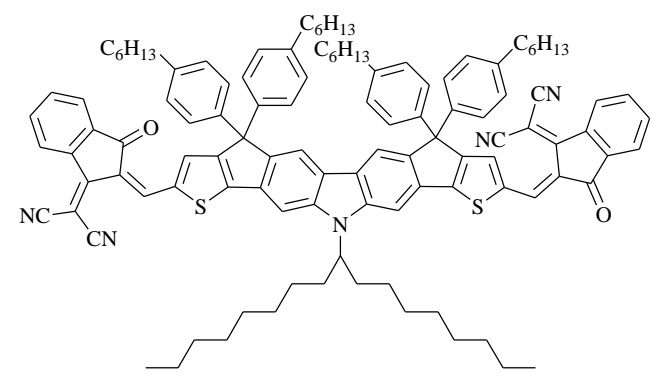

DTC-IC

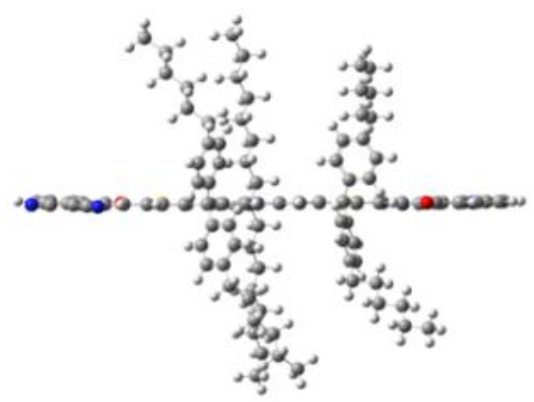

Figure 1. Optimized geometries (side view) of DTF-IC and DTC-IC 
Density functional theory calculations by the DFT (B3LYP/6-31G* level) method were performed to investigate the molecular geometries and frontier orbitals of DTF-IC and DTC-IC. The detailed frontier orbitals are described in the ESI (Table S1). The space distances between the oxygen atoms of carbonyl groups and the hydrogen atoms of the adjacent thiophene rings on the same side are only 2.04 angstrom, indicating the $\mathrm{O}-\mathrm{H}$ hydrogen-bond interactions, which facilitate the nearly flat backbone configurations of the two acceptors (Figure 1).

The synthetic routines of DTF-IC and DTC-IC are provided in Scheme 1. The para-hexylphenyl substituted DTF and DTC bromides (6a and $\mathbf{6 b}$ ) were synthesized according to the literature. ${ }^{[19]}$ The aldehydes $\mathbf{7 a}$ and $\mathbf{7 b}$ were prepared by lithiation with n-butyllithium followed by quenching with dimethylformamide (DMF). Subsequent Knoevenagel condensation between 7a/7b and INCN afforded the two molecules. All the intermediates, as well as the DTF-IC and DTC-IC, were fully characterized by ${ }^{1} \mathrm{H}-\mathrm{NMR}$ and ${ }^{13} \mathrm{C}-\mathrm{NMR}$ spectra (Figure S1-S16, ESI). The two acceptors exhibit good solubility in common organic solvents, such as chloroform, toluene and ortho-dichlorobenzene at room temperature.

\subsection{Properties of the acceptors}

The thermal properties of two acceptors were investigated by thermogravimetric analysis (TGA) and showed in Figure S17 (ESI). The corresponding 5\% weight-loss temperature $\left(\mathrm{T}_{\mathrm{d}}\right)$ are $338^{\circ} \mathrm{C}$ for DTF-IC and $344^{\circ} \mathrm{C}$ for DTC-IC, separately, indicating their good thermal stabilities.

Table 1 Optical and electrochemical properties of DTF-IC and DTC-IC

\begin{tabular}{lcccccc}
\hline \multirow{2}{*}{ Acceptor } & $\begin{array}{c}\lambda_{\max } \text { solution } \\
{[\mathrm{nm}]}\end{array}$ & $\begin{array}{c}\lambda_{\max } \text { film } \\
{[\mathrm{nm}]}\end{array}$ & $\begin{array}{c}\lambda_{\text {onset }} \\
{[\mathrm{nm}]}\end{array}$ & $\begin{array}{c}\mathrm{E}_{\mathrm{g}}{ }^{[\mathrm{a}]} \\
{[\mathrm{eV}]}\end{array}$ & $\begin{array}{c}\mathrm{E}_{\mathrm{LUMO}}[\mathrm{b}] \\
{[\mathrm{eV}]}\end{array}$ & $\begin{array}{c}\mathrm{E}_{\mathrm{HOMO}}{ }^{[\mathrm{b}]} \\
{[\mathrm{eV}]}\end{array}$ \\
\hline DTF-IC & 653 & 663 & 725 & 1.71 & -3.80 & -5.40 \\
DTC-IC & 671 & 679 & 738 & 1.68 & -3.81 & -5.41 \\
\hline [a] estimated from the onset of electronic absorption of the acceptors films $\left(\mathrm{E}_{\mathrm{g}}=1240 / \lambda_{\text {onset }}(\mathrm{nm})\right) .{ }^{[\mathrm{b}]}$ cyclic \\
voltammetry results.
\end{tabular}


The chloroform solutions of the two acceptors show strong and narrow absorption in the region of 550-700 nm with maximum extinction coefficient of $2.02 \times 10^{5} \mathrm{M}^{-1} \mathrm{~cm}^{-1}$ at $653 \mathrm{~nm}$ for DTF-IC and $2.22 \times 10^{5} \mathrm{M}^{-1} \mathrm{~cm}^{-1}$ at $671 \mathrm{~nm}$ for DTC-IC (Figure 2a). From Figure 2b, the thin films of DTF-IC exhibit strong absorption in the region from 550 to $700 \mathrm{~nm}$ with absorption onset of $725 \mathrm{~nm}$ corresponding to an optical bandgap of $1.71 \mathrm{eV}$. In contrast, the absorption edge of DTC-IC film shows significant redshift of $13 \mathrm{~nm}(738 \mathrm{~nm})$, which provide a relative small
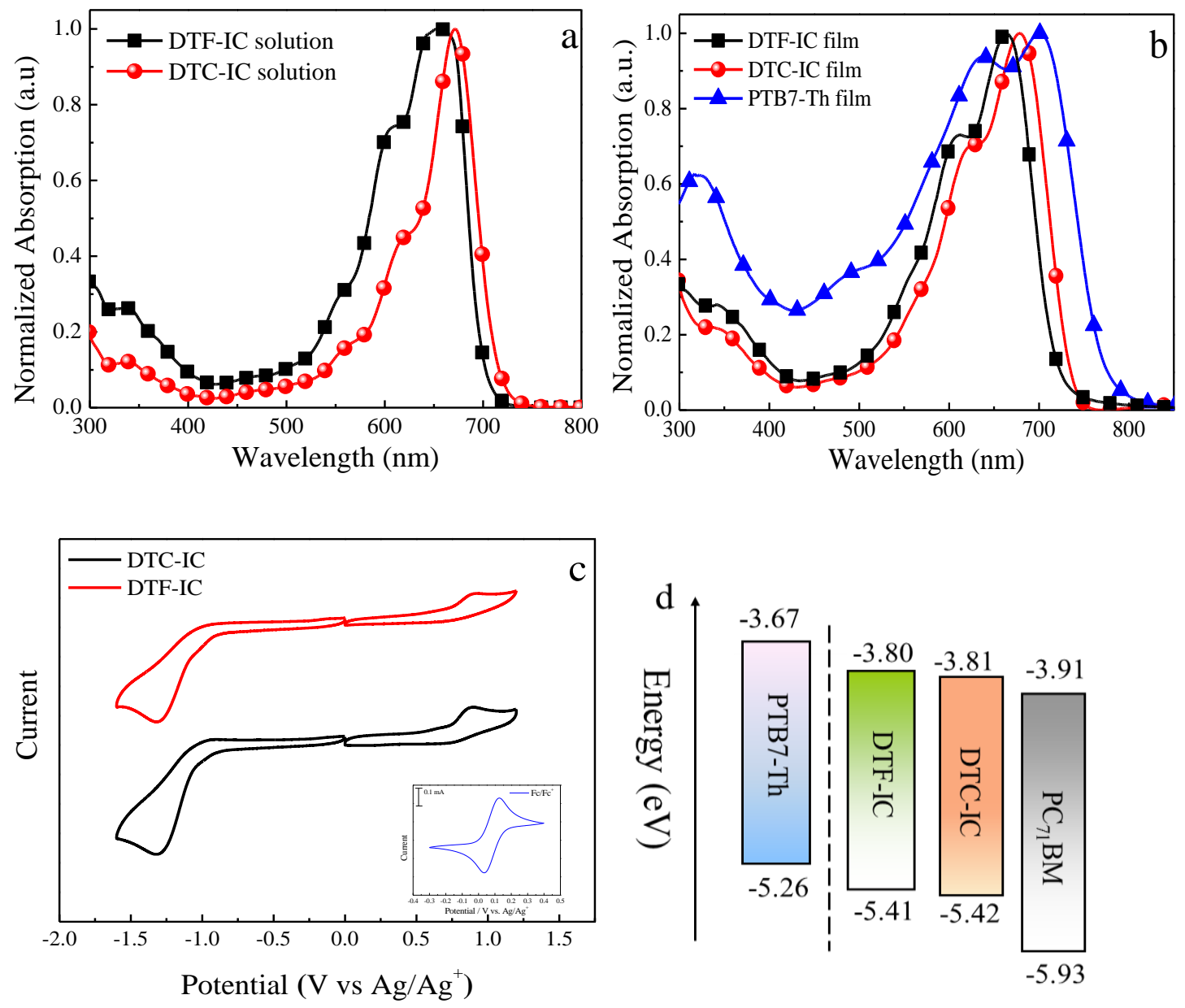

Figure 2. (a) Absorption spectra of DTF-IC and DTC-IC in $\mathrm{CHCl}_{3}$; (b) Absorption spectra of DTF-IC, DTCIC and PTB7-Th films;(c) Cyclic voltammograms of DTF-IC and DTC-IC measured in $0.1 \mathrm{~mol} / \mathrm{L} \mathrm{Bu}_{4} \mathrm{NPF}_{6}$ solutions at a scan rate of $50 \mathrm{mV} / \mathrm{s}$;(d) schematic illustration of relative positions of HOMO/LUMO energy levels of DTF-IC, DTC-IC, PTB7-Th and PC ${ }_{71}$ BM. 
optical bandgap of $1.68 \mathrm{eV}$. Obviously, the reduced bandgap of DTC-IC can be ascribed to the relatively strong electron-donating property of the carbazole unit. ${ }^{[20]}$ PTB7-Th, a promising narrow bandgap donor polymer reported by Chen ${ }^{[17]}$, was chosen as the donor material to blend with DTF-IC and DTC-IC in this study. The normalized absorption spectrum of PTB7-Th film is also given in Figure 2b. It should be pointed out that the absorption spectrum of PTB7-Th showed strong overlapping with DTF-IC and DTC-IC in the region of 500-740 nm, indicating somewhat mismatching absorption of PTB7-Th with these two acceptors. The absorption data of DTF-IC and DTC-IC are summarized in Table 1.

The electrochemical behaviours of DTF-IC and DTC-IC were investigated by cyclic voltammetry (CV) (Figure 2c). From the onset reduction potential $\left(\mathrm{E}_{\mathrm{red}}\right)$, the lowest unoccupied molecular orbital (LUMO) energy levels ( $\mathrm{E}_{\mathrm{LUMO}}$ ) are determined according to the equation $\mathrm{E}_{\mathrm{LUMO}}=-\mathrm{e}\left(\mathrm{E}_{\text {red }}+4.71\right)(\mathrm{eV})^{[21]}$ (redox potential of $\mathrm{Fc} / \mathrm{Fc}^{+}$is $0.09 \mathrm{~V}$ vs $\mathrm{Ag} / \mathrm{AgCl}$ in our $\mathrm{CV}$ measurement system). From Figure 2c, the oxidation/reduction potentials are measured as 0.70/0.91 V for DTF-IC and 0.71/0.90 V for DTC-IC, corresponding to the $\mathrm{E}_{\mathrm{HOMO}}$ and $\mathrm{E}_{\mathrm{LUMO}}$ values of -5.41/-3.80 eV (DTF-IC) and -5.42/-3.81 eV (DTC-IC), respectively. The CV data of DTF-IC and DTC-IC are presented in Table 1. We also estimated the energy levels of PTB7Th by CV. Notably, the $\mathrm{E}_{\mathrm{LumO}}(-3.67 \mathrm{eV})$ and $\mathrm{E}_{\text {Hомо }}(-5.26 \mathrm{eV})$ of PTB7-Th are only 0.13/0.14 $\mathrm{eV}$ and 0.15/0.16 eV higher than those of DTF-IC and DTC-IC, respectively, which are smaller than the empirical threshold of $0.3 \mathrm{eV}$ for effective exciton dissociation to overcome the binding energy of the excitons. However, highly effective photo-induced charge transfer are occurred between PTB7-Th and the two acceptors in the blended films, which can be confirmed by the photoluminescence (PL) quenching measurement as described in ESI (Figure S18). When excited at a wavelength of $706 \mathrm{~nm}$, the PL spectrum of PTB7-Th ranged from 720 to $850 \mathrm{~nm}$ 
with a peak value of $795 \mathrm{~nm}$. However, the PL spectra were almost totally quenched when blended with DTF-IC or DTC-IC. To make a clear comparison, the energy levels diagrams of the used materials in the PSCs and fullerene-based acceptor [6,6]-phenyl-C71 butyric acid methyl ester $\left(\mathrm{PC}_{71} \mathrm{BM}\right)$ are summarized in Figure 2d. Obviously, the two acceptors possessed similar $\mathrm{E}_{\mathrm{LUMO}}$ values, about $0.1 \mathrm{eV}$ higher than that of $\mathrm{PC}_{71} \mathrm{BM}(-3.91 \mathrm{eV}),{ }^{[22]}$ which facilitate high open-circuit voltage $\left(\mathrm{V}_{\mathrm{oc}}\right)$ in PSCs.

\subsection{Characteristics of Photovoltaic Devices}

PSCs were fabricated using inverted device structure of indium tin oxide (ITO)/Zinc oxide (ZnO)/poly[(9,9-dioctyl-2,7-fluorene)-alt-(9,9-bis(3-N,N-dimethylamino)propyl)-2,7-fluorene]

(PFN)/active layer/Al. PFN was used as cathode interlayer to modify the work function of the electrode, improve the charge extraction efficiency and reduce the recombination losses. ${ }^{[23]}$ Detailed device data are listed in the ESI (Tables S2 and Figure S19-20). The optimized device performance data are summarized in Table 2, and the corresponding $J-V$ characteristics are shown in Figure 3a. Under their optimal conditions, the PTB7-Th:DTF-IC $(1: 1.3, w / w)$ blend film displays a high open-circuit voltage $\left(\mathrm{V}_{\mathrm{oc}}\right)$ of $0.88 \mathrm{~V}, 0.01 \mathrm{~V}$ bigger than that of the PTB7Th:DTC-IC (1:1.3,w/w) based device and is coincided with its higher LUMO energy level. Both two acceptors-based devices exhibit highly similar short-circuit current density $\left(\mathrm{J}_{\mathrm{sc}}\right)$ over $14 \mathrm{~mA}$ $\mathrm{cm}^{-2}$, indicating weak effects of their absorption differences on the photo-to-current conversion process, which might be the result of the absorption overlapping of PTB7-Th with DTFIC/DTC-IC. Relative to DTF-IC, the DTC-IC based device exhibits a slightly higher fill factor (FF), due to its better solubility from the longer alkyl side-chain.

Table 2. Device performance parameters of PSCs based on PTB7-Th and two acceptors

\begin{tabular}{lllll}
\hline Acceptor & $\mathrm{V}_{\mathrm{oc}}[\mathrm{V}]$ & $\mathrm{J}_{\mathrm{sc}}\left[\mathrm{mA} / \mathrm{cm}^{2}\right]$ & $\mathrm{FF}[\%]$ & $\mathrm{PCE}^{[\mathrm{a}, \mathrm{b}]}[\%]$ \\
\hline DTF-IC & $0.87 \pm 0.01$ & $14.35 \pm 0.25$ & $53.9 \pm 0.9$ & $6.70 \pm 0.27(6.92)$
\end{tabular}




\section{\begin{tabular}{lllll}
\hline DTC-IC & $0.86 \pm 0.01$ & $14.12 \pm 0.09$ & $55.7 \pm 0.6$ & $6.80 \pm 0.16(7.02)$
\end{tabular}}

${ }^{[a]}$ Average values from 10 devices. ${ }^{[b]}$ The best PCEs are provided in parentheses.

Under their optimal conditions, both two acceptors-based devices show similar photo-tocurrent response from 450 to $800 \mathrm{~nm}$ (Figure 3b) with a maximum value of $64 \%$ at $577 \mathrm{~nm}$ for DTF-IC and 63\% at $651 \mathrm{~nm}$ for DTC-IC, respectively. Noticeably, EQE values of the two NF acceptors-based films exhibit over 50\% only across a limited range of 522-705 nm (Figure 3b). If a more complementary absorption wide-bandgap donor polymer (like $\mathbf{J 5 1}{ }^{[24]}$, J61 ${ }^{[14]}$ or PBDB-T ${ }^{[13]}$ ) is used to blend with these two acceptors, enhanced PCEs can be anticipated, especially for the DTC-IC-based devices due to its narrow bandgap.
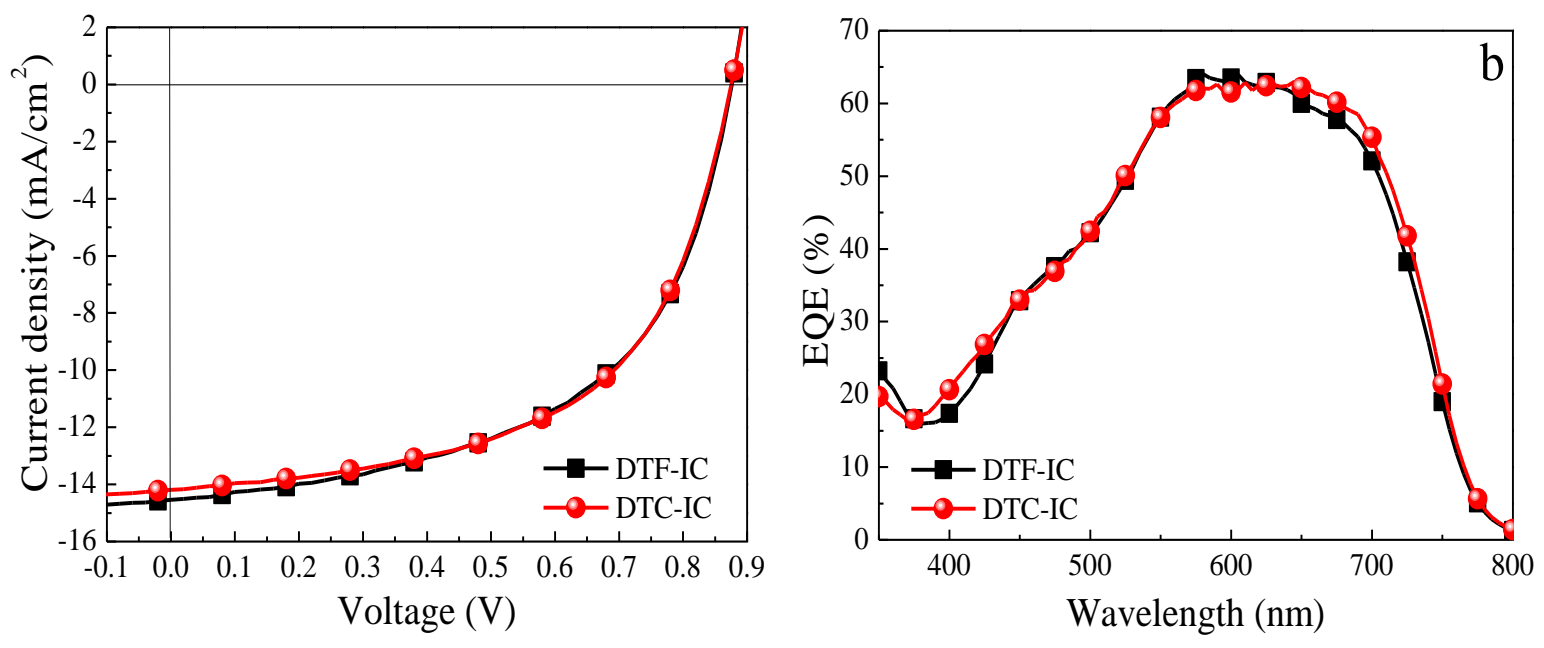

Figure 3. (a) The $J$-V curves of PSCs based on PTB7-Th:DTF-IC (1:1.3, w/w) and PTB7-Th:DTC-IC(1:1.3, w/w) under the illumination of AM 1.5G, $100 \mathrm{~mW} \mathrm{~cm}^{-2}$; (b) the corresponding EQE curves of DTF-IC and DTC-IC devices.

\subsection{Charge transport and morphology properties}

The morphology of the blend films with a weight ratio (polymer/acceptor) of 1:1.3 was investigated by atomic force microscopy (AFM). Both two acceptors-based films are very smooth with a root-mean-square (RMS) roughness of $1.16 \mathrm{~nm}$ for PTB7-Th:DTF-IC and slightly bigger RMS of $1.23 \mathrm{~nm}$ for PTB7-Th:DTC-IC, respectively (Figure 4a, 4b). As for the 
phase images (Figure 4c, 4d), clear phase separation with domain size of 5-10 nm are observed, which facilitate the effectively exciton dissociation and high FF.

To characterize molecular packing as well as crystallinity, grazing incidence wide angle X-ray scattering (GIWAXS) was used to detect pure films of two acceptors and their blend films. PTB7-Th pure film exhibits broad scattering pattern in out of plane direction corresponding to $\pi$ $\pi$ stacking peak $(\mathrm{q} \approx 1.61 \AA-1)$ in $1 \mathrm{D}$ line-cut, and also show face-on orientation relative to substrate(Figure S21, ESI). Pure DTC-IC film (Figure 5b) exhibits sharper scattering peaks than pure DTF-IC film (Figure 5a), which means DTC-IC adopted a more ordered packing and thus has better crystallinity than DTF-IC. The different crystallinities of two small molecules are remained when blending with PTB7-Th. While (100) peak disappears in PTB7-Th:DTF-IC blend film, the (100) peak in out-of-plane direction in PTB7-Th:DTC-IC blend film is remained at $\mathrm{q} \approx 0.49 \AA^{-1}$, indicating an ordered lamellar stacking. Meanwhile, double-peak fitting
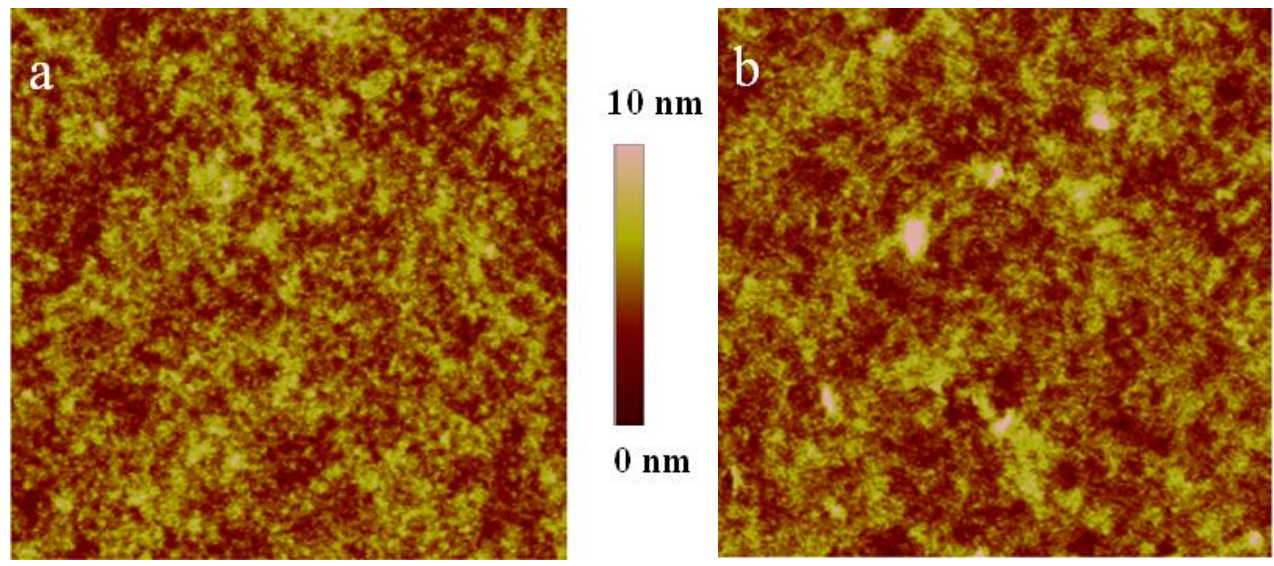

$10 \mathrm{~nm}$

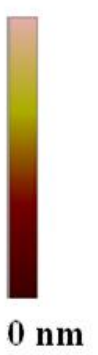



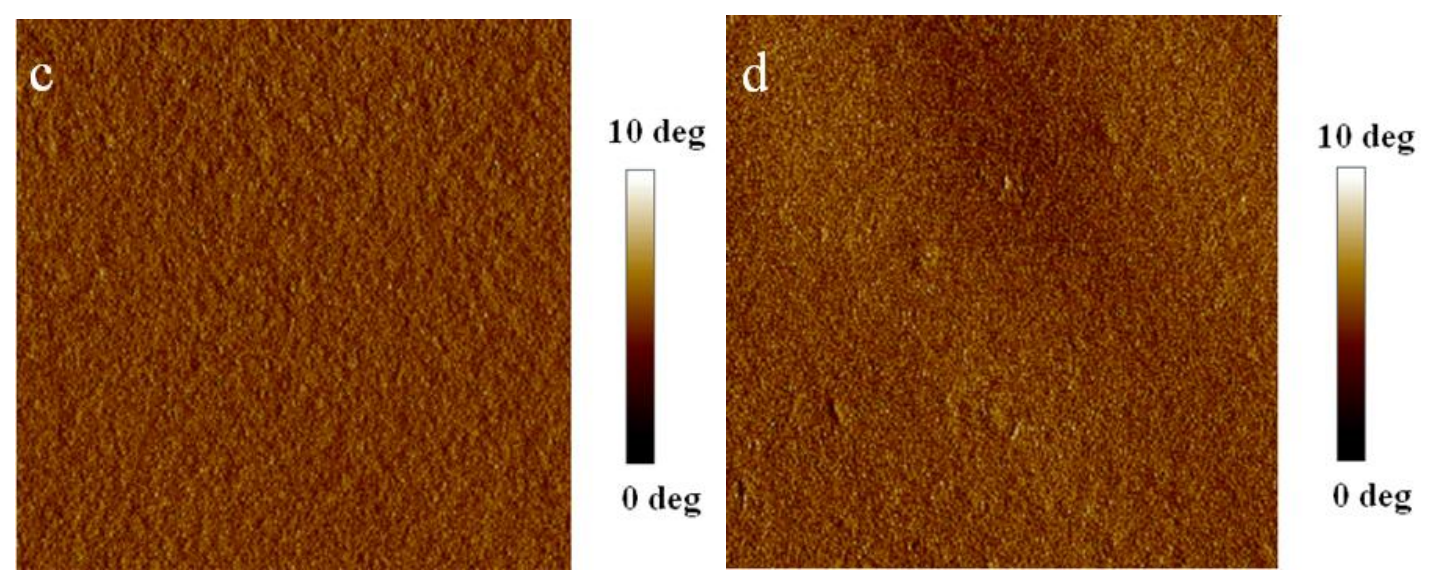

Figure 4. (a) AFM height images for PTB7-Th:DTF-IC (1:1.3) and (c) the corresponding phase images (4 $\mu \mathrm{m} \times 4 \mu \mathrm{m})$; (b) AFM height images for PTB7-Th:DTC-IC (1:1.3) and (d) the corresponding phase images (4 $\mu \mathrm{m} \times 4 \mu \mathrm{m})$.

is applied to determine the (010) peaks relating to $\pi$ - $\pi$ stacking in the out-of-plane line-cuts of two blends, because the (010) peaks of donor and acceptor are too close to recognize. The fitting result shows that both $\pi-\pi$ stacking peaks of DTF-IC and DTC-IC are located at $\mathrm{q} \approx 1.54 \AA^{-1}$ in the blend film, while the scattering peaks at $\mathrm{q} \approx 1.62 \AA^{-1}$ are attributed to PTB7-Th $\pi-\pi$ stacking. According to the Scherrer equation, ${ }^{[25]}$ the information of crystalline size is related to the width of the diffraction peaks as coherence length $\left(\mathrm{CL}=\frac{2 \pi K}{F W H M}\right.$, where $\mathrm{K}=0.9$ is a shape factor (typically $0.8-1$ ) and FWHM is the full width at half-maximum of a diffraction peak ${ }^{[26]}$ ). CL values of donor and acceptor in the blend system are calculated and listed in Table 3. CL of DTC-IC (010) peak in PTB7-Th:DTC-IC (51.4 $\AA$ ) is much greater than that of DTF-IC in PTB7-Th:DTF-IC (12.4 A). The different crystallinity of acceptors also influences the degree of order of PTB7-Th, which shows larger CL in PTB7-Th:DTC-IC (39.6 ̊̊) than in PTB7Th:DTF-IC (13.3 ^). Better crystallinity leads to better charge transport which improves the mobility of both holes and electrons as discussed below. Thus a higher FF is obtained in PTB7Th:DTC-IC than in PTB7-Th:DTF-IC. 

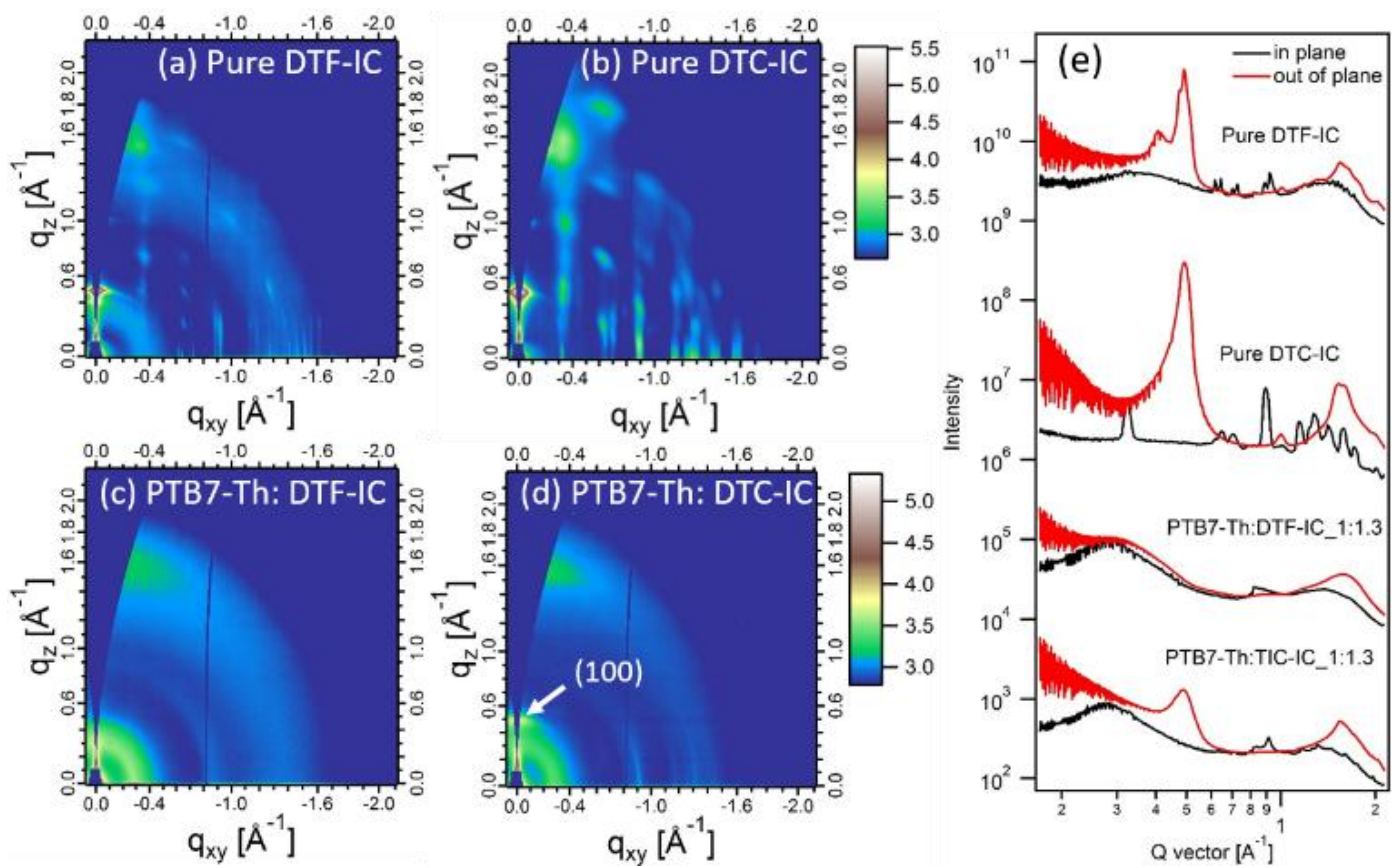

Figure 5. GIWAXS 2D patterns for (a) pure DTF-IC, (b) pure DTC-IC, (c) PTB7-Th:DTF-IC blend, (d) PTB7-Th:DTC-IC blend and (e) 1D line-cuts.

Table 3. Coherence length of GIWAXS for two blend films

\begin{tabular}{ccc}
\hline \multirow{2}{*}{ Sample } & \multicolumn{2}{c}{ Coherence Length $[\AA]$} \\
\cline { 2 - 3 } & acceptor & donor \\
\hline PTB7-Th:DTF-IC & 12.36 & 13.32 \\
PTB7-Th:DTC-IC & 51.39 & 39.57 \\
\hline
\end{tabular}

The bulk charge mobility properties of the optimized PTB7-Th:DTF-IC and PTB7-Th:DTCIC blend films were investigated by the space-charge limited current (SCLC) method. The hole and electron mobilities were measured with device structures of ITO/poly(3,4ethylenedioxythiophene):poly(styrene-sulfonate) (PEDOT:PSS)/active layer/ $\left(\mathrm{MoO}_{3}\right) / \mathrm{Al}$ and ITO/ZnO/PFN/active layer/PFN/Al, respectively. As shown in Figure S21 (ESI), the PTB7Th:DTF-IC blend films exhibit hole mobility of $2.31 \times 10^{-4} \mathrm{~cm}^{-2} \mathrm{~V}^{-1} \mathrm{~s}^{-1}$ and electron mobility of $1.37 \times 10^{-5} \mathrm{~cm}^{-2} \mathrm{~V}^{-1} \mathrm{~s}^{-1}$. For the DTC-IC based films, the hole mobility is increased to $2.82 \times 10^{-4}$ $\mathrm{cm}^{-2} \mathrm{~V}^{-1} \mathrm{~s}^{-1}$ as well as an improved electron mobility of $2.67 \times 10^{-5} \mathrm{~cm}^{-2} \mathrm{~V}^{-1} \mathrm{~s}^{-1}$. The enhanced and 
more balanced electron and hole mobility of DTC-IC-based device are contributed to the slightly higher FF value. To further investigate the performances of the two acceptors with wide bandgap polymers, J52 ${ }^{[27]}$ was used as the donor materials blended with DTC-IC and DTF-IC, an improved PCE of $8.06 \%$ was achieved for the J52:DTC-IC (1:1, w/w) based device for the complementary absorption between J52 and DTC-IC, indicating the potential application of DTC-IC in highly efficient PSCs. Detailed results will be reported in our further paper.

When we prepare this manuscript, a novel A-D-A non-fullerene small molecule (FDICTF) based on dithienocyclopentafluorene core with four octyl side-chains was reported by Chen and co- workers ${ }^{[28]}, 10 \%$ PCE was achieved when blended FDICTF with a wide bandgap polymer (PBDB-T), indicating the effectiveness and bright future of these two electron-donating cores based NF acceptors.

\section{Conclusion}

In summary, we have prepared two novel A-D-A types of non-fullerene acceptors (DTF-IC and DTC-IC) based on dithienocyclopentafluorene and dithienocyclopentacarbazole as the electron-rich cores. Benefit from its strong electron- donating property, film absorption of DTCIC shows $13 \mathrm{~nm}$ red-shifts comparing to that of DTF-IC. Under their optimal donor/acceptor weight ratios, inverted heterojunction solar cells fabricated with these two analogy molecules as acceptors and PTB7-Th as donor realized moderate PCEs of $6.92 \%$ for DTF-IC and 7.02\% for DTC-IC, respectively. Considering the potential wide structure varieties and the absorption mismatch of these two acceptors with PTB7-Th, it is believed that enhanced PCE could be realized through adopting a wide bandgap polymer with complementary absorption or structural modification to red-shift the absorption spectra of the acceptors. We believe that these results can promote the design and synthesis of novel NF acceptors for high-performance PSCs. 


\section{Acknowledgements}

Thanks for the support from Ministry of science and technology (No. 2016YFA0200700), NSFC (No. 21504066, 21504067 and 61274054). X-ray data was acquired at beamlines 7.3 .3 at the Advanced Light Source, which is supported by the Director, Office of Science, Office of Basic Energy Sciences, of the U.S. Department of Energy under Contract No. DE-AC0205CH11231. The authors thank Chenhui Zhu at beamline 7.3.3, and Cheng Wang at beamline 11.0.1.2 for assistance with data acquisition. The authors thank Dr. Xiaolong Yang and Pro Guijiang Zhou of Xi'an Jiaotong University for the assistance with PL measurements.

\section{References}

[1] Li Y. Molecular design of photovoltaic materials for polymer solar cells: toward suitable electronic energy levels and broad absorption. Acc Chem Res 2012; 45: 723-733.

[2] Yu G, Gao J, Hummelen JC, Wudl F, Heeger AJ. Polymer photovoltaic cells: enhanced efficiencies via a network of internal donor-acceptor heterojunctions. Science 1995; 270: 1789-1791.

[3] Henson ZB, Mullen K, Bazan GC. Design strategies for organic semiconductors beyond the molecular formula. Nat Chem 2012; 4: 699-704.

[4] (a) Liao SH, Jhuo HJ, Yeh PN, Cheng YS, Li YL, Lee YH, Sharma S, Chen SA. Single junction inverted polymer solar cell reaching power conversion efficiency $10.31 \%$ by employing dual-doped zinc oxide nanofilm as cathode interlayer. Sci Rep 2014; 4:6813. (b) Zheng Z, Zhang S, Zhang J, Qin Y, Li W, Yu R, Wei Z, Hou J. Over $11 \%$ efficiency in tandem polymer solar cells featured by a low-band-gap polymer with fine-tuned properties. Adv Mater 2016; 28: 5133-5138.

[5] (a) Liu Y, Zhao J, Li Z, Mu C, Ma W, Hu H, Jiang K, Lin H, Ade H, Yan H. Aggregation and morphology control enables multiple cases of high-efficiency polymer solar cells. Nat Commun 2014; 5: 5293. (b) Zhao J, Li Y, Yang G, Jiang K, Lin H, Ade H, Ma W, Yan H. Efficient organic solar cells processed from hydrocarbon solvents. Nature Energy 2016; 1: 15027.

[6] He Z, Xiao B, Liu F, Wu H, Yang Y, Xiao S, Wang C, Russell TP, Cao Y. Single-junction polymer solar cells with high efficiency and photovoltage. Nat Photo 2015; 9: 174-179.

[7] Ouyang X, Peng R, Ai L, Zhang X, Ge Z. Efficient polymer solar cells employing a non-conjugated smallmolecule electrolyte. Nat Photo 2015; 9: 520- 524.

[8] Lin Y, Zhan X. Non-fullerene acceptors for organic photovoltaics: an emerging horizon. Mater Horiz 2014; 1: $470-488$.

[9] Zhao W, Qian D, Zhang S, Li S, Inganäs O, Gao F, Hou J. Fullerene-free polymer solar cells with over 11\% efficiency and excellent thermal stability. Adv Mater 2016; 28: 4734-4739.

[10] Lin Y, Zhao F, Wu Y, Chen K, Xia Y, Li G, Prasad SKK, Zhu J, Huo L, Bin H, Zhang ZG, Guo X, Zhang M, Sun Y, Gao F, Wei Z, Ma W, Wang C, Hodgkiss J, Bo Z, Inganäs O, Li Y, Zhan X. Mapping polymer 
donors toward high-efficiency fullerene free organic solar cells. Adv Mater 2017; DOI: 10.1002/adma.201604155.

[11] Lin Y, Wang J, Zhang ZG, Bai H, Li Y, Zhu D, Zhan X. An electron acceptor challenging fullerenes for efficient polymer solar cells. Adv Mater 2015; 27: 1170-1174.

[12] Lin Y, Zhao F, He Q, Huo L, Wu Y, Parker TC, Ma W, Sun Y, Wang C, Zhu D, Heeger AJ, Marder SR, Zhan X. High-performance electron acceptor with thienyl side chains for organic photovoltaics. J Am Chem Soc 2016; 138: 4955-4961.

[13] (a) Li S, Ye L, Zhao W, Zhang S, Mukherjee S, Ade H, Hou J. Energy-level modulation of smallmolecule electron acceptors to achieve over $12 \%$ efficiency in polymer solar cells. Adv Mater 2016; 28: $9423-$ 9429. (b) Zhao W, Li S, Zhang S, Liu X, Hou J. Ternary polymer solar cells based on two acceptors and one donor for achieving 12.2\% efficiency. Adv Mater 2017; DOI: 10.1002/adma.201604059.

[14] Yang Y, Zhang ZG, Bin H, Chen S, Gao L, Xue L, Yang C, Li Y. Side-chain isomerization on an n-type organic semiconductor ITIC acceptor makes $11.77 \%$ high efficiency polymer solar cells. J Am Chem Soc 2016; 138: 15011-15018.

[15] Baran D, Kirchartz T, Wheeler S, Dimitrov S, Abdelsamie M, Gorman J, Ashraf RS, Holliday S, Wadsworth A, Gasparini N, Kaienburg P, Yan H, Amassian A, Brabec CJ, Durrant JR, McCulloch I. Reduced voltage losses yield $10 \%$ efficient fullerene free organic solar cells with $>1 \mathrm{~V}$ open circuit voltages. Energy Environ Sci 2016; 9: 3783- 3793.

[16] (a) Li M, Liu Y, Ni W, Liu F, Feng H, Zhang Y, Liu T, Zhang H, Wan X, Kan B, Zhang Q, Russell TP, Chen Y. A simple small molecule as an acceptor for fullerene-free organic solar cells with efficiency near $8 \%$. J Mater Chem A 2016; 4: 10409-10413. (b) Li Y, Zhong L, Wu FP, Yuan Y, Bin HJ, Jiang ZQ, Zhang Z, Zhang ZG, Li Y, Liao LS. Non-fullerene polymer solar cells based on a selenophene-containing fused-ring acceptor with photovoltaic performance of 8.6\%. Energy Environ Sci 2016; 9: 3429-3435. (c) Li Y, Qian D, Zhong L, Lin JD, Jiang ZQ, Zhang ZG, Zhang Z, Li Y, Liao LS, Zhang F. A fused-ring based electron acceptor for efficient non-fullerene polymer solar cells with small HOMO offset. Nano Energy 2016; 27: 430438. (d) Li Y, Liu X, Wu FP, Zhou Y, Jiang ZQ, Song B, Xia Y, Zhang ZG, Gao F, Inganäs O, Li Y, Liao LS. Non-fullerene acceptor with low energy loss and high external quantum efficiency: towards high performance polymer solar cells. J Mater Chem A 2016; 4: 5890-5897.

[17] Liao SH, Jhuo HJ, Cheng YS, Chen SA. Fullerene derivative-doped zinc oxide nanofilm as the cathode of inverted polymer solar cells with low-bandgap polymer (PTB7-Th) for high performance. Adv Mater 2013; 25: 4766- 4771.

[18] Hexemer A, Bras W, Glossinger J, Schaible E, Gann E, Kirian R, MacDowell A, Church M, Rude B, Padmore H. A SAXS/WAXS/GISAXS beamline with multilayer monochromator. J. Phys. Conf. Ser. 2010; 247: 012007.

[19] Lee TH, Wu KY, Lin TY, Wu JS, Wang CL, Hsu CS. Role of the comonomeric units in reaching linear backbone, high solid-state order and charge mobilities in heptacyclic arene-based alternating copolymers. Macromolecules 2013; 46: 7687-7695.

[20] Park SH, Roy A, Beaupre S, Cho S, Coates N, Moon JS, Moses D, Leclerc M, Lee K, Heeger AJ. Bulk heterojunction solar cells with internal quantum efficiency approaching 100\%. Nat Photo 2009; 3: 297-302.

[21] Hou J, Tan Z, Yan Y, He Y, Yang C, Li Y. Synthesis and photovoltaic properties of two-dimensional conjugated polythiophenes with bi(thienylenevinylene) side chains. J Am Chem Soc 2006; 128: 4911-4916.

[22] He Y, Chen HY, Hou J, Li Y. Indene- $\mathrm{C}_{60}$ bisadduct: a new acceptor for high-performance polymer solar cells. J Am Chem Soc 2010; 132: 1377-1382.

[23] He Z, Zhang C, Xu X, Zhang L, Huang L, Chen J, Wu H, Cao Y. Largely enhanced efficiency with a PFN/Al bilayer cathode in high efficiency bulk heterojunction photovoltaic cells with a low bandgap polycarbazole donor. Adv Mater 2011; 23: 3086-3089.

[24] Gao L, Zhang ZG, Bin H, Xue L, Yang Y, Wang C, Liu F, Russell TP, Li Y. High-efficiency nonfullerene polymer solar cells with medium bandgap polymer donor and narrow bandgap organic semiconductor acceptor. Adv Mater 2016; 28: 8288-8295.

[25] Smilgiesa D-M. Scherrer grain-size analysis adapted to grazing-incidence scattering with area detectors. Erratum. J Appl Cryst 2013;46:286-286

[26] Rivnay J, Mannsfeld SCB, Miller CE, Salleo A, Toney MF. Quantitative determination of organic semiconductor microstructure from the molecular to device scale. Chem Rev 2012; 112:5488-5519 
[27] Bin H, Zhang Z-G, Gao L, Chen S, Zhong L, Xue L, Yang C, Li Y. Non-fullerene polymer solar cells based on alkylthio and fluorine substituted 2D-conjugated polymers reach $9.5 \%$ efficiency. $\mathrm{J}$ Am Chem Soc 2016;138:4657-4664

[28] Qiu N, Zhang H, Wan X, Li C, Ke X, Feng H, Kan B, Zhang H, Zhang Q, Lu Y, Chen Y. A new nonfullerene electron acceptor with a ladder type backbone for high-performance organic solar cells. Adv Mater 2017; DOI: 10.1002/adma.201604964. 